\title{
EFFECT OF ADDING ANTIBIOTIC, OREGANO ESSENTIAL OIL AND GARLIC POWDER ON GROWTH PERFORMANCE, CARCASS TRAITS AND INTESTINAL PATHOGENIC MICRORGANISMS OF QUAILS
}

\author{
Zangabel S.M. El-sayed, O.H.M. El-Garhy*, M.M. Abdella and G.A. El-Sayaad \\ Animal Production Department, Faculty of Agriculture, Benha University, Egypt \\ * Corresponding author: osama.alsayed@fagr.bu.edu.eg
}

\section{SUMMARY}

This study was conducted to evaluate the effects of dietary supplementation of antibiotic, oregano essential oil and garlic powder as feed additives in quail diets on the productive performance. A total number of 540 unsexed one week old Japanese chicks were randomly distributed into nine experimental treatments, each of 60 birds (3 replicates of 20 birds each). Chicks of the $1^{\text {st }}$ experimental group were fed on basal diet without additives and considered as a control group. Chicks of the $2^{\text {nd }}$ and $3^{\text {rd }}$ experimental groups were fed on basal diets supplemented with Oxytetracycline at levels of 0.5 and $1.0 \mathrm{~g} / \mathrm{kg}$ diet, respectively. Chicks of the $4^{\text {th }}, 5^{\text {th }}$ and $6^{\text {th }}$ groups were fed on basal diets supplemented with oregano essential oil (OEO) at levels of 0.5, 1.0 and 1.5 $\mathrm{g} / \mathrm{kg}$ diet, respectively. While, chicks of the $7^{\text {th }}, 8^{\text {th }}$ and $9^{\text {th }}$ groups were fed basal diets supplemented with garlic powder (GP) at levels of $0.1,0.2$ and $0.3 \mathrm{~g} / \mathrm{kg}$ diet, respectively. The present results showed that highly significant differences $(p \leq 0.001)$ were found in the average body weight $(L B W)$, body weight gain $(B W G)$, growth rate (GR), feed intake (FI), feed conversion (FC), carcass traits, mortality rate, economic efficiency $(E E)$ and the total microbial population count in small intestine. The highest significant improvement in (LBW), $(B W G),(G R),(F I),(F C)$, carcass traits, $(E E)$ and the lowest intestine pathogenic populations content and mortality rate were observed in the group of chicks that were fed diet supplemented with OEO at levels of 1.5 and $1.0 \mathrm{~g} / \mathrm{kg}$ diet, respectively compared with the other experimental groups and the control group, followed by those that were fed diet supplemented with $0.2 \mathrm{~g} / \mathrm{kg}$ GP. However, from the economic point of view, it could be concluded that feeding on the basal diet supplemented with GP level of $0.2 \mathrm{~g} / \mathrm{kg}$ diet showed lower feed cost than feeding basal diet supplemented with OEO at both levels 1.5 and $1.0 \mathrm{~g} / \mathrm{kg}$ diet. It was clear from the obtained results that the control chicks had the lowest productive performance and the higher mortality rate. Therefore, it could be recommended to use OEO at levels of 1.5 and $1.0 \mathrm{~g} / \mathrm{kg}$ diet and GP at levels $0.2 \mathrm{~g} / \mathrm{kg}$ diet as growth promoters instead of antibiotics, to improve the productive performance and the economic efficiency of quails.

Keywords: Quails, oregano oil, garlic, antibiotic, growth performance, economical efficiency and intestine pathogenic populations

\section{INTRODUCTION}

In recent years using of antibiotics as growth promoters in animal and poultry feed has been banned in several countries including the European countries due to concerns about their residues in animal tissues and subsequent induction of emerging antibiotic resistant strains of microorganisms. This change has stimulated the researchers to look for an alternative supplements, the medicinal plants or their essential oils are among these alternative growth promoters (Williams and Losa, 2002; Lee et al., 2003 and Hernandez et al., 2004). Both extracts and essential oil of medicinal plants are characterized with several effects including antimicrobial activity (Giannenas et al., 2003; Lee et al., 2004 and Fukayama et al., 2005) antioxidant activity (Basmacioğlu, et al., 2004; Giannenas et al., 2005 and Florou-Paneri et al., 2006) enhancement of the immune system (Dorhoi et al., 2006) and led to improved poultry and animal performance.

Oregano (Origanum vulgare) is a species of Origanum genus that belongs to the family of
Lamiaceae. Several studies have demonstrated that using the oregano products (oil extract or its dried leaf) as feed additives has enhanced the performance of broiler chicken (Modeva and Profirov, 2003; Giannenas et al., 2003 and Lihua et al., 2007) and decreased microbial populations in gastrointestinal tract such as Clostridium perfringens and E. coli (Giannenas et al., 2003 and Fukayama et al., 2005).

The supplementation of poultry diets with oregano essential oil (OEO) enhanced growth performance, improved carcass quality, and reduced mortality rates (Williams and Losa, 2001). These properties of OEO were attributed to containing a hydroxyl group in their phenolic components, thymol and carvacrol (Ben Arfa et al., 2006).

Several in vitro studies have demonstrated that essential oils eliminate pathogenic bacteria, among them E. coli, Salmonella spp. (including Salmonella enteritidis and Salmonella typhimurium), Pseudomonas aeruginosa, Staphylococcus aureus, Staphylococcus epidermis, Klebsiella pneumoniae, Shigella spp., Proteus vulgaris, and Bacillus cereus 
(Azaz et al., 2004; Bagamboula et al., 2004 and Penalver et al., 2005).

Garlic (Allium sativum) is one of the oldest cultivated plants (Moyers, 1996). Several studies have concluded that garlic as a medical plant showed several effects including antimicrobial activity (Iwalokun et al., 2004; Corzo-Martínez et al., 2007 and Onibi et al., 2009); inhibition of platelet aggregation (Apitz-Castro et al., 1983); reduction in arterial blood pressure (McMahon and Vargas, 1993); prevention of fat infiltration of liver (Kim et al., 1995) and stimulation of immune functions (Sumiyoshi, 1997).

Garlic has rich organic sulfur compounds and precursors (allicin, diallyl sulfide, and diallyltrisulfide), where allicin is the potentially active component of garlic. These compounds provide garlic its biological properties and have been identified as having the hypocholesterolemic effect in human and animal (Aouadi et al., 2000 and Chowdhury et al., 2002). Allicin and its derivatives has been shown to be bacteriostatic active against both gram positive and gram negative microorganisms as well as fungi such as Candida albicans and viruses including influenza viruses (Chang and Cheong, 2008). Additionally, garlic and garlic extracts have shown to have antioxidant activity in various meat types (Yin and Cheng, 2003 and Sallam et al., 2004).

Supplementing broiler chicken diets with garlic can produce chicken meat with favorable lipid profiles and can enhance meat quality as shown by sensory panels. It was found that thigh meat from chickens fed a garlic-supplemented diet had better texture and flavor (Kim et al., 2009).

The aim of this study was to evaluate the effect of feeding quail birds diets supplemented with different levels of antibiotic (Oxytetracycline), oregano essential oil and garlic powder on growth performance, economical efficiency and microbial count of pathogenic microorganisms in the small intestine of Japanese quail (Couturinx couturinx japanico).

\section{MATERIALS AND METHODS}

The experimental work of this study was carried out at the Poultry Research Farm of Animal Production Department, Faculty of Agriculture at
Moshtohor, Benha University. The chemical analyses and microbiological studies were conducted at the laboratories of Animal Production Department, microbiological laboratories of Botany Department of the same Faculty and the same University.

\section{Experimental Design}

A total number of 540 unsexed one week old Japanese quail chicks obtained from Quail Bird Station, belong to Faculty of Agriculture, Ain Shams University were used in this study. Chicks chosen were of nearly similar live body weight and randomly distributed into nine experimental treatments each of 60 chicks in three replicates $(20$ chicks/each replicate).The experimental design is shown in Table (1), accordingly, a total of nine experimental diets were studied.

\section{Experimental Diets}

Quails of the nine experimental treatments were fed diets contained about $24 \%$ crude protein (CP) and $3000 \mathrm{ME} \mathrm{Kcal} / \mathrm{kg}$ diet. Birds of all experimental treatments were fed ad-libitum during 1-7 weeks of age. The growing diet was formulated according to the recommended requirements of NRC, (1994) as shown in Table (2).

\section{Housing and Management of Experimental Quails}

Chicks in all experimental treatments were kept under similar management, hygienic and environmental conditions. Battery cages with electric heater were used for brooding chicks and artificial lighting was provided over the 24 hours daily during the whole experimental period. Brooding temperature was maintained at $37^{\circ} \mathrm{C}$ during the first week of chick's age then was decreased by $2^{\circ} \mathrm{C}$ weekly until the end of brooding period. Therefore, normal temperature with natural ventilation through the windows was applied up to seven weeks of age. Chicks were vaccinated against Newcastle disease three times, Gumbora and Avian influenza diseases, firstly with Hitchner IB on the fifth day of age and twice with Lasto strain at the 18 and 35 days of age. Chicks were vaccinated also against infection bursal disease (Gumbora) two times in drinking water at 13 and 23 days of age.

Table 1. Description of experimental design

\begin{tabular}{lc}
\hline Dietary treatments & Treatments No \\
\hline Control & $\mathrm{T} 1$ \\
Antibiotic $($ Oxytetracyclin $20 \%)$ & $\mathrm{T} 2$ \\
Antibiotic $($ Oxytetracyclin $20 \% \mathrm{~g} / \mathrm{kg}$ diet $) 1.0 \mathrm{~g} / \mathrm{kg}$ diet & $\mathrm{T} 3$ \\
Oregano oil $0.5 \mathrm{~g} / \mathrm{kg}$ diet & $\mathrm{T} 4$ \\
Oregano oil $1.0 \mathrm{~g} / \mathrm{kg}$ diet & $\mathrm{T} 5$ \\
Oregano oil $1.5 \mathrm{~g} / \mathrm{kg}$ diet & $\mathrm{T} 6$ \\
Garlic powder $0.1 \mathrm{~g} / \mathrm{kg}$ diet & $\mathrm{T} 7$ \\
Garlic powder $0.2 \mathrm{~g} / \mathrm{kg}$ diet & $\mathrm{T} 8$ \\
Garlic powder $0.3 \mathrm{~g} / \mathrm{kg}$ diet & $\mathrm{T} 9$ \\
\hline
\end{tabular}


Table 2. Composition and calculated analysis of the basal diet

\begin{tabular}{lc}
\hline Ingredients & $\%$ \\
\hline Yellow corn & 56.00 \\
Soyabean meal (44\%) & 27.90 \\
Corn gluten (60\%) & 12.00 \\
di-calcium phosphate & 1.70 \\
Calcium carbonate & 1.35 \\
Salt & 0.25 \\
Hy-mix broiler premix & 0.30 \\
DL.methionine & 0.20 \\
Lysine & 0.30 \\
Calculated analysis** & 2948.3 \\
ME(kcal/kg) & 24.39 \\
CP (\%) & 0.97 \\
Calcium & 0.45 \\
Available phosphorus (\%)
\end{tabular}

*Each $3.0 \mathrm{Kg}$ of the Hy-mix broiler premix, manufactured by Agri-Vet Company, Egypt contains: Vit. A, 12000000 IU ; Vit. D3 2000000 IU ; Vit. E, 10 g ; Vit. K3, 2.0 g ; Vit. B1, 1.0 g ; Vit. B2, 5 g ; Vit. B6, 1.5 g; Vit. B12,10 mg ; choline chloride, $250 \mathrm{~g}$; biotin, $50 \mathrm{mg}$; folic acid, $1 \mathrm{~g}$; nicotinic acid , $30 \mathrm{~g}$; Ca pantothenate, $10 \mathrm{~g} ; \mathrm{Zn}, 50 \mathrm{~g} ; \mathrm{Cu}, 10 \mathrm{~g}$; Fe, $30 \mathrm{~g}$; Co, $100 \mathrm{mg}$; Se, $100 \mathrm{mg} ; \mathrm{I}, 1 \mathrm{~g}$; Mn, $60 \mathrm{~g}$ and anti-oxidant, $10 \mathrm{~g}$, and complete to $3.0 \mathrm{Kg}$ by calcium carbonate.

** According to NRC, (1994)

\section{Data Collection and Estimated Parameters a) Live body weight, body weight gain and growth rate:}

Weekly live body weight (LBW) was obtained by weighing the birds individually to the nearest gram in early morning before receiving any feed and water through the experimental period. Individual LBW were totaled and divided by the number of chicks to obtain the average LBW.

Average live body weight gain (BWG) was calculated by subtracting the average initial LBW of a certain period from the average final LBW of the same period. Weight gains and growth rate were calculated according to the following formulas suggested by Brody, (1949).

Weight gain $=\mathrm{W} 2-\mathrm{W} 1$

Growth rate $\%=(\mathrm{W} 2-\mathrm{W} 1 /(\mathrm{W} 2+\mathrm{W} 1) / 2) \times 100$

Whereas: $\mathrm{W} 1$ and $\mathrm{W} 2$ are individual body weights at the two successive periods

\section{b) Feed intake and feed conversion:}

Daily feed intake (FI) per chick was calculated every 7 days interval for each group and sub-group as follows:

Average FI / bird / day = Weekly feed intake / birds number $\times 7$

Feed conversion (FC) was calculated as the amount of feed required for producing a unit of gain according to the following formula:

$\mathrm{FC}=$ (Average FI / chick / week / Average BWG / chick / week)

\section{c) Carcass traits:}

Slaughter was performed to determine carcass traits at the end of the experimental period ( 7 weeks of age). Five birds from each experimental treatment were randomly chosen, and the assigned birds were deprived of feed for 16 hours prior to slaughter, thereafter they were individually weighed to the nearest gram (pre-slaughter weight). The birds were then slaughtered according to recommended Islamic tradition method by cutting the throat and jugular vein near the first neck vertebra with a sharp knife. After complete bleeding, birds were individually reweighed and each bird was dipped in a water bath for two minutes and feathers were removed by hand. Shanks and head were separated, the birds were then eviscerated and intestine, gizzard, lungs, spleen, liver, heart and reproductive organs were removed. The carcass (included the front part with wings and the hind part) and giblets (empty gizzard, liver and heart) were separately weighed. The giblets weight did not include spleen weight in quails because it is very small (about $0.1 \mathrm{~g}$ ).

The proportional weights of carcass, giblets and total edible parts to pre-slaughter weight were calculated as following:-

1 - Carcass $\%=($ Carcass weight $/$ pre-slaughter weight ) $\times 100$

2- Giblets weight $\%=$ (Giblets weight $/$ preslaughter weight $) \times 100$

3- Total edible parts $\%=$ Carcass weight + giblets weight / pre-slaughter weight $\times 100$

\section{d) Total microbial populations count in small intestine:}

Under aseptic conditions, small intestine contents for individual birds of each group were picked up for the microbial counts. Five birds were randomly selected to enumerate the microbial populations in small intestine (duodenum, jejunum, and ileum) of quail by using various dehydrated media (Biolife Ltd, Italy). The media was prepared and sterilized 
according to the manufacturer's instructions before being poured into sterile Petri dishes. The media that was used included tryptic soy agar (for total microbial count), Sabouradu dextrose agar (for cultivation and isolation of yeasts and molds), Pseudomonas selective agar (selective medium for isolation of $P$. aeruginosa), giolitti-cantoni agar with potassium tellurite $1 \%$ (for enumeration of Staphylococcus aureus), Mac Conkey agar OMS $\mathrm{W} / \mathrm{O} \mathrm{CV}$ (selective and differential medium for detection of coliforms and enteric pathogens) and SS agar (for selective medium for isolation of Salmonella spp and Shigella spp). Enumeration of microbial populations by plate count methods was carried out according to American Public Health Association, 1993.

\section{e) Mortality rate and economic efficiency:}

Accumulative mortality rate \% was obtained by adding the number of dead birds during the experimental periods and divided by the total number of chicks at the beginning of the experiment.

The economic efficiency (EEf) was calculated according to the cost of one-kg feed (included the price of feed additives) and the prices of one $\mathrm{kg}$ body gain during the same time of experiment. The values of EEf were calculated as the net revenue per unit of total coast. Relative EEf was calculated assuming that the EEf of the control $=100$.

\section{Statistical Analysis:}

Data were statistically analyzed using ANOVA procedures of SAS (SAS, 2004), and significance of the differences between means was determined using Duncan's new multiple range test (Duncan, 1955) for all of experimental treatments.

The statistical analysis for traits of body weight, body weight gain, growth rate, feed intake and conversion, mortality rate, carcass traits, economical efficiency were carried out according to the following linear model 1:

$$
\begin{aligned}
& \mathbf{X}_{\mathbf{i j}}=\boldsymbol{\mu}+\mathbf{T}_{\mathbf{i}}+\mathbf{e}_{\mathbf{i j}} \\
& \text { Whereas: } \\
& \quad \text { Xijk }=\text { the } \mathrm{N}^{\text {th }} \text { observations } \\
& \mu=\text { the overall mean } \\
& \mathrm{T}_{\mathrm{i}}=\text { the effect of the } \mathrm{i}^{\text {th }} \text { treatments } \\
& \mathrm{e}_{\mathrm{ij}}=\text { the random error assumed to be }
\end{aligned}
$$

independently and randomly distributed

While, statistical analysis of microbial count in the small intestinal parts was carried out according to the following model 2:

$\mathbf{X}_{\mathrm{ijk}}=\boldsymbol{\mu}+\mathbf{T}_{\mathrm{i}}+\mathbf{P}_{\mathrm{j}}+\mathbf{T} \mathbf{P}_{\mathrm{ij}}+\mathbf{e}_{\mathrm{ijk}}$

Whereas:

$\mathrm{X}_{\mathrm{ijk}}=$ the $\mathrm{N}^{\text {th }}$ observations

$\mu=$ the overall mean.

$\mathrm{T}_{\mathrm{i}}=$ the effect of $\mathrm{i}^{\text {th }}$ treatments

$P_{j}=$ the effect of the $j^{\text {th }}$ part of the small intestinal parts.

$\mathrm{TP}_{\mathrm{ij}}=$ the interaction between $\mathrm{i}^{\text {th }}$ treatment and $\mathrm{j}^{\text {th }}$ part of the small intestine.

$\mathrm{e}_{\mathrm{ijk}}=$ random error assumed to be independently and randomly distributed.

\section{RESULTS AND DISCUSSION}

\section{Live body weight:}

Results of average live body weight (LBW) of quail chicks as affected by feeding diets supplied with different levels of antibiotic (Oxytetracyclin), oregano essential oil (OEO) and Garlic powder (GP) are presented in Table (3). The initial body weight of quail chicks of the experimental treatments ranged between 31.60-32.60 g with no significant differences among the different treatments.

Table 3. Effect ( \pm SE) of dietary antibiotic, oregano essential oil and garlic powder levels on live body weight of Japanese quail chicks at the different experimental ages

\begin{tabular}{cccccccc}
\hline \multirow{2}{*}{ Treatments } & $\mathbf{7}$ Body weight (g) at \\
\cline { 2 - 8 } 1wk & 2wk & 3wk & 4wk & 5wk & 6wk & 1-6wks \\
\hline T1 & $31.9 \pm 0.32$ & $64.8 \pm 0.69^{\mathrm{g}}$ & $113.7 \pm 0.63^{\mathrm{g}}$ & $145.5 \pm 2.08^{\mathrm{g}}$ & $179.6 \pm 1.49^{\mathrm{h}}$ & $203.5 \pm 1.99^{\mathrm{h}}$ & $123.1 \pm 0.53^{\mathrm{h}}$ \\
T2 & $32.4 \pm 0.32$ & $67.5 \pm 0.69^{\mathrm{ef}}$ & $124.5 \pm 0.63^{\mathrm{f}}$ & $164.0 \pm 2.08^{\mathrm{f}}$ & $201.6 \pm 1.49^{\mathrm{g}}$ & $227.7 \pm 1.99^{\mathrm{g}}$ & $136.3 \pm 0.53^{\mathrm{g}}$ \\
T3 & $31.6 \pm 0.32$ & $72.1 \pm 0.69^{\mathrm{d}}$ & $130.5 \pm 0.63^{\mathrm{d}}$ & $190.8 \pm 2.08^{\mathrm{d}}$ & $231.4 \pm 1.49^{\mathrm{d}}$ & $262.3 \pm 1.99^{\mathrm{d}}$ & $153.1 \pm 0.53^{\mathrm{d}}$ \\
T4 & $31.8 \pm 0.32$ & $69.2 \pm 0.69^{\mathrm{e}}$ & $126.9 \pm 0.63^{\mathrm{e}}$ & $187.5 \pm 2.08^{\mathrm{d}}$ & $225.9 \pm 1.49^{\mathrm{e}}$ & $252.9 \pm 1.99^{\mathrm{e}}$ & $149.0 \pm 0.53^{\mathrm{e}}$ \\
T5 & $32.4 \pm 0.32$ & $85.6 \pm 0.69^{\mathrm{b}}$ & $145.5 \pm 0.63^{\mathrm{b}}$ & $207.8 \pm 2.08^{\mathrm{b}}$ & $254.4 \pm 1.49^{\mathrm{b}}$ & $286.9 \pm 1.99^{\mathrm{b}}$ & $168.8 \pm 0.53^{\mathrm{b}}$ \\
T6 & $32.6 \pm 0.32$ & $92.1 \pm 0.69^{\mathrm{a}}$ & $153.2 \pm 0.63^{\mathrm{a}}$ & $221.5 \pm 2.08^{\mathrm{a}}$ & $270.8 \pm 1.49^{\mathrm{a}}$ & $304.9 \pm 1.99^{\mathrm{a}}$ & $179.2 \pm 0.53 \mathrm{a}$ \\
T7 & $31.7 \pm 0.32$ & $72.8 \pm 0.69^{\mathrm{d}}$ & $128.4 \pm 0.63^{\mathrm{e}}$ & $189.0 \pm 2.08^{\mathrm{d}}$ & $226.0 \pm 1.49^{\mathrm{e}}$ & $255.7 \pm 1.99^{\mathrm{e}}$ & $150.6 \pm 0.53^{\mathrm{e}}$ \\
T8 & $32.3 \pm 0.32$ & $80.3 \pm 0.69^{\mathrm{c}}$ & $138.9 \pm 0.63^{\mathrm{c}}$ & $200.1 \pm 2.08^{\mathrm{c}}$ & $243.7 \pm 1.49^{\mathrm{c}}$ & $275.5 \pm 1.99^{\mathrm{c}}$ & $161.8 \pm 0.53^{\mathrm{c}}$ \\
T9 & $31.6 \pm 0.32$ & $66.2 \pm 0.69^{\mathrm{fg}}$ & $123.4 \pm 0.63^{\mathrm{f}}$ & $176.5 \pm 2.08^{\mathrm{e}}$ & $212.5 \pm 1.49^{\mathrm{f}}$ & $238.2 \pm 1.99^{\mathrm{f}}$ & $141.4 \pm 0.53^{\mathrm{f}}$ \\
\hline
\end{tabular}

$\mathrm{a}, \mathrm{b} . .$. and $\mathrm{h}$ means having different letters at the same column are significantly ( $\mathrm{P} \leq 0.05$ ) different

$\mathrm{T} 1=$ Control, $\mathrm{T} 2=$ Antibiotic (Oxytetracyclin $20 \%$ ) $0.5 \mathrm{~g} / \mathrm{kg}$ diet, T3= Antibiotic (Oxytetracyclin 20\% ) $1.0 \mathrm{~g} / \mathrm{kg}$ diet, $\mathrm{T} 4=$ Oregano oil $0.5 \mathrm{~g} / \mathrm{kg}$ diet, $\mathrm{T} 5=$ Oregano oil $1.0 \mathrm{~g} / \mathrm{kg}$ diet, $\mathrm{T} 6=$ Oregano oil $1.5 \mathrm{~g} / \mathrm{kg}$ diet, $\mathrm{T} 7=\mathrm{Garlic}$ powder $0.1 \mathrm{~g} / \mathrm{kg}$ diet, $\mathrm{T} 8=$ Garlic powder $0.2 \mathrm{~g} / \mathrm{kg}$ diet, $\mathrm{T} 9=$ Garlic powder $0.3 \mathrm{~g} / \mathrm{kg}$ diet.

Data presented in Table (3) show that quail chicks fed diets supplied with OEO at level of $1.5 \mathrm{~g} / \mathrm{kg}$ diet (T6) had the highest significant $(\mathrm{P} \leq 0.05)$ average LBW during all the periods, followed by those fed the diet supplied with oregano essential oil with level $1.0 \mathrm{~g} / \mathrm{kg}$ diet (T5). Concerning the garlic powder levels, it was clearly evidence that quail chicks fed the diet supplied with garlic powder at level of $0.2 \mathrm{~g} /$ $\mathrm{kg}$ diet (T8) had come in the third order in the average LBW then, those fed diets supplied with antibiotic at level $1.0 \mathrm{~g} / \mathrm{kg}$ diet compared with those 
fed the control diet (T1) and the other treatment groups.

The improvement in body weight of quail chicks fed diets contains oregano oil could be attributed to their ability to destroy pathogens in digestive system and consequently increase the production of digestive enzymes which improve the utilization of digestive products, as revealed by (Hernandez et al., 2004).

These results are in agreement with those who found an improvement in body weight of broilers fed diets supplemented with medicinal plant extracts (Jamroz and Kamel, 2002; Ertas et al., 2005; Bozkurt et al., 2009 and Abdel-Wareth et al., 2012), who found an improvement in body weight of broilers fed diets supplemented with medicinal plant extracts. Also, the results related to the effect of garlic powder levels supplementations are relatively similar to those reported by Raeesi et al. (2010) who found that broiler chicks fed diets supplemented with 1 and $3 \%$ garlic powder have significant increase in body weight.

\section{Body weight gain}

Significant variations $(\mathrm{P} \leq 0.05)$ were found in average body weight gain (BWG) of quails, $\mathrm{g} / \mathrm{bird} /$ week due to different treatments applied at all times of the experiment. The highest averages of
BWG were observed in the treatments of chicks fed diets contain OEO at levels of 1.5 and $1.0 \mathrm{~g} / \mathrm{kg}$ diet (T6 and T5) during the entire period of the experiment with averages of 272.4 and $254.6 \mathrm{~g}$, respectively, followed by quail chicks fed diet contains GP at level $0.2 \mathrm{~g} / \mathrm{kg}$ diet (T8), 243.3g then, those fed diet contains antibiotic at level of $1.0 \mathrm{~g} / \mathrm{kg}$ diet (T3), 230.7g. However, the lowest average of BWG was observed in chicks fed the control diet (T1) $171.6 \mathrm{~g}$ (Table, 4).

The results obtained agree with those reported by Fotea et al., (2008) who showed that the highest body weight gain in broiler chicks was observed with chicks fed on diet supplemented with OEO at level of $1 \%(2484 \mathrm{~g})$, followed by those received level $0.7 \%$ (2463 g) and level $0.3 \%$ (2401g) compared with control group (2365 g). In addition, Tiihonen et al., (2010) found that broiler chickens fed on diet supplemented with mix derived from oregano, anise and clove had significantly higher BWG by approximately $16 \%$ compared to the control (chicks fed on basal diet). Furthermore, Raeesi et al., (2010) stated that broiler chickens that received garlic powder in their finisher diet had greater body weight gain than others fed garlic powder in the starter diet.

Table 4. Effect (mean \pm SE) of dietary antibiotic, oregano essential oil and garlic powder levels on body weight gain of Japanese quail chicks at the different experimental periods

\begin{tabular}{ccccccc}
\hline \multirow{2}{*}{ Treatments } & \multicolumn{7}{c}{ Body weight gain (g) at } \\
\cline { 2 - 7 } & $\mathbf{1 - 2 w k}$ & $\mathbf{2 - 3 w k}$ & $\mathbf{3 - 4 w k}$ & $\mathbf{4 - 5 w k}$ & $\mathbf{5 - 6 w k}$ & $\mathbf{1 - 6 w k s}$ \\
\hline T1 & $32.8 \pm 0.79^{\mathrm{f}}$ & $49.0 \pm 0.75^{\mathrm{e}}$ & $31.8 \pm 2.39^{\mathrm{e}}$ & $34.1 \pm 2.67^{\mathrm{d}}$ & $23.9 \pm 2.49^{\mathrm{c}}$ & $171.6 \pm 2.06^{\mathrm{h}}$ \\
T2 & $35.2 \pm 0.79^{\mathrm{ef}}$ & $57.0 \pm 0.75^{\mathrm{cd}}$ & $39.5 \pm 2.39^{\mathrm{d}}$ & $37.7 \pm 2.67^{\mathrm{cd}}$ & $26.1 \pm 2.49^{\mathrm{abc}}$ & $195.4 \pm 2.06^{\mathrm{g}}$ \\
T3 & $40.5 \pm 0.79^{\mathrm{d}}$ & $58.5 \pm 0.75^{\mathrm{bc}}$ & $60.2 \pm 2.39^{\mathrm{bc}}$ & $40.7 \pm 2.67^{\mathrm{bcd}}$ & $30.9 \pm 2.49^{\mathrm{abc}}$ & $230.7 \pm 2.06^{\mathrm{d}}$ \\
T4 & $37.4 \pm 0.79^{\mathrm{e}}$ & $57.8 \pm 0.75^{\mathrm{bc}}$ & $60.6 \pm 2.39^{\mathrm{abc}}$ & $38.4 \pm 2.67^{\mathrm{bcd}}$ & $27.0 \pm 2.49^{\mathrm{abc}}$ & $221.2 \pm 2.06^{\mathrm{e}}$ \\
T5 & $53.2 \pm 0.79^{\mathrm{b}}$ & $60.0 \pm 0.75^{\mathrm{ab}}$ & $62.3 \pm 2.39^{\mathrm{ab}}$ & $46.7 \pm 2.67^{\mathrm{ab}}$ & $32.5 \pm 2.49^{\mathrm{ab}}$ & $254.6 \pm 2.06^{\mathrm{b}}$ \\
T6 & $59.5 \pm 0.79^{\mathrm{a}}$ & $61.1 \pm 0.75^{\mathrm{a}}$ & $68.3 \pm 2.39^{\mathrm{a}}$ & $49.3 \pm 2.67^{\mathrm{a}}$ & $34.2 \pm 2.49^{\mathrm{a}}$ & $272.4 \pm 2.06^{\mathrm{a}}$ \\
T7 & $41.2 \pm 0.79^{\mathrm{d}}$ & $55.6 \pm 0.75^{\mathrm{d}}$ & $60.6 \pm 2.39^{\mathrm{abc}}$ & $37.0 \pm 2.67^{\mathrm{cd}}$ & $29.7 \pm 2.49^{\mathrm{abc}}$ & $224.0 \pm 2.06^{\mathrm{e}}$ \\
T8 & $48.0 \pm 0.79^{\mathrm{c}}$ & $58.6 \pm 0.75^{\mathrm{bc}}$ & $61.2 \pm 2.39^{\mathrm{ab}}$ & $43.6 \pm 2.67^{\mathrm{abc}}$ & $31.9 \pm 2.49^{\mathrm{abc}}$ & $243.3 \pm 2.06^{\mathrm{c}}$ \\
T9 & $34.6 \pm 0.79^{\mathrm{f}}$ & $57.3 \pm 0.75^{\mathrm{cd}}$ & $53.1 \pm 2.39^{\mathrm{c}}$ & $36.0 \pm 2.67^{\mathrm{cd}}$ & $25.7 \pm 2.49^{\mathrm{bc}}$ & $206.7 \pm 2.06^{\mathrm{f}}$ \\
\hline
\end{tabular}

$\mathrm{a}, \mathrm{b} \ldots$... and $\mathrm{h}$ means having different letters at the same column are significantly $(\mathrm{P} \leq 0.05)$ different.

$\mathrm{T} 1=$ Control, $\mathrm{T} 2=$ Antibiotic $($ Oxytetracyclin $20 \%$ ) $0.5 \mathrm{~g} / \mathrm{kg}$ diet, $\mathrm{T} 3=$ Antibiotic (Oxytetracyclin 20\% ) $1.0 \mathrm{~g} / \mathrm{kg}$ diet, $\mathrm{T} 4=$ Oregano oil $0.5 \mathrm{~g} / \mathrm{kg}$ diet, $\mathrm{T} 5=$ Oregano oil $1.0 \mathrm{~g} / \mathrm{kg}$ diet, $\mathrm{T} 6=$ Oregano oil $1.5 \mathrm{~g} / \mathrm{kg}$ diet, $\mathrm{T} 7=\mathrm{Garlic}$ powder $0.1 \mathrm{~g} / \mathrm{kg}$ diet, $\mathrm{T} 8=$ Garlic powder $0.2 \mathrm{~g} / \mathrm{kg}$ diet, $\mathrm{T} 9=$ Garlic powder $0.3 \mathrm{~g} / \mathrm{kg}$ diet.

\section{Growth Rate:}

Data on growth rate is shown in Table (5). It is clearly evidence that chicks fed diet supplemented with OEO at level $1.5 \mathrm{~g} / \mathrm{kg}$ diet (T6) showed the highest growth rate $(161.4 \%)$ followed by those fed diet supplemented with OEO at level $1.0 \mathrm{~g} / \mathrm{kg}$ diet (T5) which recorded average growth rate $159.5 \%$ followed by those fed diet supplemented with GP at level of $0.2 \mathrm{~g} / \mathrm{kg}$ diet (T8), 158.1\% compared with the other treatments and control group (T1) which recorded the lowest growth rate $(145.8 \%)$. These results show the same trend observed with both body weight and body weight gain in this study. This is because the growth rate calculation is based on the body weight as a relative value from the average body weight of birds at the same period.

These results agree with those of Dickens et al., (2000); Hassan et al. (2004) and Bunyapraphatsara, (2007) who recorded an improvement in growth performance and the rate of growth due to supplementation with herbs and spices in broiler diets. In addition Fotea et al. (2008) and Symeon et al. (2009) concluded that feeding on diet supplemented with oregano essential oil significantly improved growth performance and growth rate of broiler compared with control groups.

Results related to garlic powder in the current study, agree with those reported by Tollba and Hassan (2003) and Raeesi et al. (2010) who found 
significant improvement in growth rate of broiler chicks fed on diets supplemented with garlic powder.

Table 5. Effect (Mean \pm SE) of dietary antibiotic, oregano essential oil and garlic powder levels on growth rate of Japanese quails chicks at the different experimental periods

\begin{tabular}{ccccccc}
\hline \multirow{2}{*}{ Treatments } & \multicolumn{7}{c}{ Rate of growth (\%) at } \\
\cline { 2 - 7 } & $\mathbf{1 - 2 w k}$ & $\mathbf{2 - 3 w k}$ & $\mathbf{3 - 4 w k}$ & $\mathbf{4 - 5 w k}$ & $\mathbf{5 - 6 w k}$ & $\mathbf{1 - 6 w k s}$ \\
\hline T1 & $68.0 \pm 1.21^{\mathrm{f}}$ & $54.9 \pm 0.82^{\mathrm{c}}$ & $24.5 \pm 1.59^{\mathrm{b}}$ & $21.0 \pm 1.51$ & $12.5 \pm 0.97$ & $145.8 \pm 0.54^{\mathrm{g}}$ \\
T2 & $70.3 \pm 1.21^{\text {ef }}$ & $59.4 \pm 0.82^{\mathrm{ab}}$ & $27.3 \pm 1.59^{\mathrm{b}}$ & $20.7 \pm 1.51$ & $12.2 \pm 0.97$ & $150.3 \pm 0.54^{\mathrm{f}}$ \\
T3 & $78.1 \pm 1.21^{\mathrm{d}}$ & $57.7 \pm 0.82^{\mathrm{b}}$ & $37.5 \pm 1.59^{\mathrm{a}}$ & $19.3 \pm 1.51$ & $12.5 \pm 0.97$ & $157.0 \pm 0.54^{\mathrm{cd}}$ \\
T4 & $74.1 \pm 1.21^{\mathrm{e}}$ & $59.0 \pm 0.82^{\mathrm{ab}}$ & $38.5 \pm 1.59^{\mathrm{a}}$ & $18.6 \pm 1.51$ & $11.3 \pm 0.97$ & $155.4 \pm 0.54^{\mathrm{d}}$ \\
T5 & $90.3 \pm 1.21^{\mathrm{b}}$ & $51.9 \pm 0.82^{\mathrm{de}}$ & $35.2 \pm 1.59^{\mathrm{a}}$ & $20.2 \pm 1.51$ & $12.0 \pm 0.97$ & $159.5 \pm 0.54^{\mathrm{b}}$ \\
T6 & $95.5 \pm 1.21^{\mathrm{a}}$ & $49.9 \pm 0.82^{\mathrm{e}}$ & $36.5 \pm 1.59^{\mathrm{a}}$ & $20.0 \pm 1.51$ & $11.9 \pm 0.97$ & $161.4 \pm 0.54^{\mathrm{a}}$ \\
T7 & $78.8 \pm 1.21^{\mathrm{d}}$ & $55.2 \pm 0.82^{\mathrm{c}}$ & $38.2 \pm 1.59^{\mathrm{a}}$ & $17.8 \pm 1.51$ & $12.3 \pm 0.97$ & $155.9 \pm 0.54^{\mathrm{d}}$ \\
T8 & $85.3 \pm 1.21^{\mathrm{c}}$ & $53.5 \pm 0.82^{\mathrm{cd}}$ & $36.1 \pm 1.59^{\mathrm{a}}$ & $19.6 \pm 1.51$ & $12.3 \pm 0.97$ & $158.1 \pm 0.54^{\mathrm{bc}}$ \\
T9 & $70.9 \pm 1.21^{\text {ef }}$ & $60.4 \pm 0.82^{\mathrm{a}}$ & $35.4 \pm 1.59^{\mathrm{a}}$ & $18.5 \pm 1.51$ & $11.4 \pm 0.97$ & $153.2 \pm 0.54^{\mathrm{e}}$ \\
\hline
\end{tabular}

$\mathrm{a}, \mathrm{b}$....and g means having different letters at the same column are significantly $(\mathrm{P} \leq 0.05)$ different.

$\mathrm{T} 1=$ Control, $\mathrm{T} 2=$ Antibiotic (Oxytetracyclin $20 \%$ ) $0.5 \mathrm{~g} / \mathrm{kg}$ diet, $\mathrm{T} 3=$ Antibiotic (Oxytetracyclin 20\% ) $1.0 \mathrm{~g} / \mathrm{kg} \mathrm{diet,} \mathrm{T} 4=$ Oregano oil $0.5 \mathrm{~g} / \mathrm{kg}$ diet, $\mathrm{T} 5=$ Oregano oil $1.0 \mathrm{~g} / \mathrm{kg}$ diet, $\mathrm{T} 6=$ Oregano oil $1.5 \mathrm{~g} / \mathrm{kg}$ diet, $\mathrm{T} 7=\mathrm{Garlic}$ powder $0.1 \mathrm{~g} / \mathrm{kg}$ diet, $\mathrm{T} 8=$ Garlic powder $0.2 \mathrm{~g} / \mathrm{kg}$ diet, $\mathrm{T} 9=$ Garlic powder $0.3 \mathrm{~g} / \mathrm{kg}$ diet.

\section{Feed intake:}

Results in Table (6) show significant variations $(\mathrm{P} \leq 0.05)$ in feed intake $(\mathrm{FI})$ of quail birds due to treatments applied during the experimental periods, except at both 1-2 and 4-5 weeks of age. It is clear that there was no characterized trend in average FI among all birds due to the treatments applied. However, the lowest $(\mathrm{P} \leq 0.05)$ FI values were recorded by chicks of $\mathrm{T} 1$ (control) and $\mathrm{T} 2$, being 15.1 and $15.6 \mathrm{~g} / \mathrm{bird} /$ day, respectively, Whereas FI ranged between 16.1 and $16.4 \mathrm{~g} / \mathrm{bird} /$ day for chicks of all other treatments with non-significant differences.

The above results agree with those of Çabuk et al., (2003) who reported that FI of quail birds was not affected by the supplementation of diets with herbs essential oil mixture. Furthermore, Raeesi et al., (2010) concluded that broiler chicken received garlic at levels $(0.5,1$ and $3 \%)$ had higher FI during the whole experimental period compared to the control group.

Table 6. Effect (Mean \pm SE) of dietary antibiotic, oregano essential oil and garlic powder levels on feed intake of Japanese quail chicks at the different experimental periods

\begin{tabular}{clccccc}
\hline \multirow{2}{*}{ Treatments } & \multicolumn{7}{c}{ Average feed intake (g/bird/day) } \\
\cline { 2 - 7 } & $\mathbf{1 - 2 w k}$ & $\mathbf{2 - 3 w k}$ & $\mathbf{3 - 4 w k}$ & $\mathbf{4 - 5 w k}$ & $\mathbf{5 - 6 w k}$ & $\mathbf{1 - 6}_{\mathbf{w k s}}$ \\
\hline T1 & $8.3 \pm 0.13$ & $14.8 \pm 0.13^{\mathrm{a}}$ & $16.2 \pm 0.14^{\mathrm{d}}$ & $18.6 \pm 0.21$ & $17.6 \pm 0.24^{\mathrm{c}}$ & $15.1 \pm 0.09^{\mathrm{d}}$ \\
T2 & $8.5 \pm 0.13$ & $14.9 \pm 0.13^{\mathrm{a}}$ & $16.5 \pm 0.14^{\mathrm{bcd}}$ & $18.8 \pm 0.21$ & $19.4 \pm 0.24^{\mathrm{b}}$ & $15.6 \pm 0.09^{\mathrm{c}}$ \\
T3 & $8.7 \pm 0.13$ & $14.8 \pm 0.13^{\mathrm{a}}$ & $16.9 \pm 0.14^{\mathrm{ab}}$ & $18.8 \pm 0.21$ & $225 \pm 0.24^{\mathrm{a}}$ & $16.3 \pm 0.09^{\mathrm{ab}}$ \\
T4 & $8.6 \pm 0.13$ & $15.0 \pm 0.13^{\mathrm{a}}$ & $17.0 \pm 0.14^{\mathrm{a}}$ & $18.8 \pm 0.21$ & $22.7 \pm 0.24^{\mathrm{a}}$ & $16.4 \pm 0.09^{\mathrm{a}}$ \\
T5 & $8.5 \pm 0.13$ & $14.7 \pm 0.13^{\mathrm{ab}}$ & $16.7 \pm 0.14^{\mathrm{abc}}$ & $18.8 \pm 0.21$ & $22.1 \pm 0.24^{\mathrm{a}}$ & $16.2 \pm 0.09^{\mathrm{ab}}$ \\
T6 & $8.5 \pm 0.13$ & $14.3 \pm 0.13^{\mathrm{b}}$ & $16.8 \pm 0.14^{\mathrm{abc}}$ & $18.8 \pm 0.21$ & $22.3 \pm 0.24^{\mathrm{a}}$ & $16.1 \pm 0.09^{\mathrm{ab}}$ \\
T7 & $8.5 \pm 0.13$ & $17.0 \pm 0.13^{\mathrm{a}}$ & $17.1 \pm 0.14^{\mathrm{a}}$ & $18.8 \pm 0.21$ & $22.1 \pm 0.24^{\mathrm{a}}$ & $16.3 \pm 0.09^{\mathrm{ab}}$ \\
T8 & $87 \pm 0.13$ & $14.7 \pm 0.13^{\mathrm{a}}$ & $17.0 \pm 0.14^{\mathrm{a}}$ & $18.8 \pm 0.21$ & $22.6 \pm 0.24^{\mathrm{a}}$ & $16.4 \pm 0.09^{\mathrm{a}}$ \\
T9 & $8.5 \pm 0.13$ & $14.8 \pm 0.13^{\mathrm{a}}$ & $16.4 \pm 0.14^{\mathrm{cd}}$ & $18.5 \pm 0.21$ & $22.2 \pm 0.24^{\mathrm{a}}$ & $16.1 \pm 0.09^{\mathrm{b}}$ \\
\hline
\end{tabular}

$\mathrm{a}, \mathrm{b} \ldots$...and c means having different letters at the same column are significantly $(\mathrm{P} \leq 0.05)$ different.

$\mathrm{T} 1=$ Control, $\mathrm{T} 2=$ Antibiotic $($ Oxytetracyclin $20 \%$ ) $0.5 \mathrm{~g} / \mathrm{kg}$ diet, $\mathrm{T} 3=$ Antibiotic $($ Oxytetracyclin $20 \%$ ) $1.0 \mathrm{~g} / \mathrm{kg}$ diet, $\mathrm{T} 4=$ Oregano oil $0.5 \mathrm{~g} / \mathrm{kg}$ diet, $\mathrm{T} 5=$ Oregano oil $1.0 \mathrm{~g} / \mathrm{kg}$ diet, $\mathrm{T} 6=$ Oregano oil $1.5 \mathrm{~g} / \mathrm{kg}$ diet, $\mathrm{T} 7=\mathrm{Garlic}$ powder $0.1 \mathrm{~g} / \mathrm{kg}$ diet, $\mathrm{T} 8=$ Garlic powder $0.2 \mathrm{~g} / \mathrm{kg}$ diet, $\mathrm{T} 9=$ Garlic powder $0.3 \mathrm{~g} / \mathrm{kg}$ diet.

\section{Feed conversion:}

Significant differences $(\mathrm{P} \leq 0.05)$ were found in feed conversion (FC) of quails due to the feeding of diets contained antibiotics, oregano essential oil (OEO) and garlic powder levels (GP) during most of the periods of estimation (except the period from 5 to 6 weeks of age). Quails that were fed the diet supplemented with OEO at level of $1.5 \mathrm{~g} / \mathrm{kg}$ diet (T6) recorded the best $\mathrm{FC}$ values during all the experimental periods (Table, 7 ).

Results presented in Table (7) show the best average $\mathrm{FC}$ value (2.07 $\mathrm{g}$ feed/g gain) was achieved by chicks of T6 followed by that of chicks of T5 (1.0g OEO/ kg diet) and T8 (0.2 g GP/kg diet), being 2.22 and $2.36 \mathrm{~g}$ feed/ g gain, respectively. However, the lowest improving in FC was achieved by chicks of control T1 being $3.08 \mathrm{~g}$ feed/ $\mathrm{g}$ gain.

It could be concluded that adding of oregano essential oil and garlic powder levels improved FC of quails and this may be attributed to their action as antimicrobial and antioxidant substances that lead to increase feed utilization and improve the growth performance as well. 
These results are in agreement with those reported by Çabuk et al. (2014) who found that feed conversion ratio (FCR) of quail birds was significantly improved when they were fed on diets supplemented with essential oil mixture and antibiotics. In addition, Alp et al. (2012) stated that dietary oregano essential oil and anti-coccidial drugs supplementation significantly improved the FCR $(\mathrm{P} \leq 0.05)$ of broiler chickens from 21 to 42 days and 1

Table 7. Effect (Mean \pm SE) of dietary antibiotic, oregano essential oil and garlic powder levels on feed conversion ratio of Japanese quail chicks at the different experimental periods

\begin{tabular}{ccccccc}
\hline \multirow{2}{*}{ Treatments } & \multicolumn{5}{c}{ Average feed conversion (g feed/ g gain) } \\
\cline { 2 - 6 } & $\mathbf{1 - 2 w k}$ & $\mathbf{2 - 3 w k}$ & $\mathbf{3 - 4 w k}$ & $\mathbf{4 - 5 w k}$ & $\mathbf{5 - 6 w k}$ & $\mathbf{1 - 6} \mathbf{w k s}$ \\
\hline T1 & $1.77 \pm 0.03^{\mathrm{a}}$ & $1.92 \pm 0.03^{\mathrm{a}}$ & $3.78 \pm 0.27^{\mathrm{a}}$ & $3.94 \pm 0.22^{\mathrm{a}}$ & $5.19 \pm 0.43$ & $3.08 \pm 0.02^{\mathrm{a}}$ \\
T2 & $1.70 \pm 0.03^{\mathrm{a}}$ & $1.83 \pm 0.03^{\mathrm{abc}}$ & $3.01 \pm 0.27^{\mathrm{a}}$ & $3.54 \pm 0.22^{\mathrm{abc}}$ & $5.21 \pm 0.43$ & $2.80 \pm 0.02^{\mathrm{b}}$ \\
T3 & $1.50 \pm 0.03^{\mathrm{c}}$ & $1.78 \pm 0.03^{\mathrm{cd}}$ & $1.97 \pm 0.27^{\mathrm{b}}$ & $3.24 \pm 0.22^{\mathrm{abcd}}$ & $5.22 \pm 0.43$ & $2.48 \pm 0.02^{\mathrm{e}}$ \\
T4 & $1.61 \pm 0.03^{\mathrm{b}}$ & $1.81 \pm 0.03^{\mathrm{bc}}$ & $1.96 \pm 0.27^{\mathrm{b}}$ & $3.44 \pm 0.22^{\mathrm{abc}}$ & $5.93 \pm 0.43$ & $2.60 \pm 0.02^{\mathrm{d}}$ \\
T5 & $1.12 \pm 0.03^{\mathrm{e}}$ & $1.71 \pm 0.03^{\mathrm{de}}$ & $1.88 \pm 0.27^{\mathrm{b}}$ & $2.85 \pm 0.22^{\mathrm{cd}}$ & $4.85 \pm 0.43$ & $2.22 \pm 0.02^{\mathrm{g}}$ \\
T6 & $1.00 \pm 0.03^{\mathrm{f}}$ & $1.63 \pm 0.03^{\mathrm{e}}$ & $1.71 \pm 0.27^{\mathrm{b}}$ & $2.67 \pm 0.22^{\mathrm{d}}$ & $4.60 \pm 0.43$ & $2.07 \pm 0.02^{\mathrm{h}}$ \\
T7 & $1.45 \pm 0.03^{\mathrm{c}}$ & $1.88 \pm 0.03^{\mathrm{ab}}$ & $1.98 \pm 0.27^{\mathrm{b}}$ & $3.57 \pm 0.22^{\mathrm{abc}}$ & $5.21 \pm 0.43$ & $2.55 \pm 0.02^{\mathrm{d}}$ \\
T8 & $1.27 \pm 0.03^{\mathrm{d}}$ & $1.76 \pm 0.03^{\mathrm{cd}}$ & $1.95 \pm 0.27^{\mathrm{b}}$ & $3.04 \pm 0.22^{\mathrm{bcd}}$ & $5.23 \pm 0.43$ & $2.36 \pm 0.02^{\mathrm{f}}$ \\
T9 & $1.71 \pm 0.03^{\mathrm{a}}$ & $1.81 \pm 0.03^{\mathrm{bc}}$ & $2.18 \pm 0.27^{\mathrm{b}}$ & $3.62 \pm 0.22^{\mathrm{ab}}$ & $6.07 \pm 0.43$ & $2.72 \pm 0.02^{\mathrm{c}}$ \\
\hline
\end{tabular}

$\mathrm{a}, \mathrm{b} \ldots$...and $\mathrm{h}$ means having different letters at the same column are significantly $(\mathrm{P} \leq 0.05)$ different.

$\mathrm{T} 1=$ Control, $\mathrm{T} 2=$ Antibiotic (Oxytetracyclin $20 \%$ ) $0.5 \mathrm{~g} / \mathrm{kg}$ diet, $\mathrm{T} 3=$ Antibiotic (Oxytetracyclin 20\% ) $1.0 \mathrm{~g} / \mathrm{kg}$ diet, $\mathrm{T} 4=$ Oregano oil $0.5 \mathrm{~g} / \mathrm{kg}$ diet, $\mathrm{T} 5=$ Oregano oil $1.0 \mathrm{~g} / \mathrm{kg}$ diet, $\mathrm{T} 6=$ Oregano oil $1.5 \mathrm{~g} / \mathrm{kg}$ diet, $\mathrm{T} 7=\mathrm{Garlic}$ powder $0.1 \mathrm{~g} / \mathrm{kg}$ diet, $\mathrm{T} 8=$ Garlic powder $0.2 \mathrm{~g} / \mathrm{kg}$ diet, $\mathrm{T} 9=$ Garlic powder $0.3 \mathrm{~g} / \mathrm{kg}$ diet.

\section{Carcass traits and meat yield:}

Data presented in Table (8) show significant variations $(\mathrm{P} \leq 0.05)$ in absolute LBW and proportional weights of carcass, giblets and total edible parts weights of quails due to dietary feed additives applied for the experimental treatments. The highest proportional weights of carcass, giblets and total edible parts were observed in birds fed diets supplemented with OEO at level $1.5 \mathrm{~g} / \mathrm{kg}$ diet (T6) (66.2, 5.7 and $71.9 \%$, respectively) followed by those fed diets supplemented with OEO level 1.0 $\mathrm{g} / \mathrm{kg}$ diet (T5) (64.3, 5.4 and 69.7\%, respectively). While, those fed diets supplemented with GP at level $0.2 \mathrm{~g} / \mathrm{kg}$ diet (T8) was third and recorded proportional weights of carcass, giblets and total edible parts, being 63.6, 5.1 and $68.6 \%$, respectively. However, birds fed the control diet (T1) had the lowest proportional weights of carcass, giblets and total edible parts averages $(60.6,4.7$ and $65.2 \%$, respectively). While, quail chicks fed diets supplemented with antibiotic at either level 0.5 or 1.0 $\%$ (T2 and T3) had weights for carcass, giblets and total edible parts that were intermediate between those recorded by both control treatment and other treatments applied.

It could be concluded that the improvement in proportional weights of carcass, giblets and total edible parts due to adding different dietary levels of both OEO and GP may be attributed to their beneficial effect on increasing feed utilization as previously mentioned which improve growth to 42 days of age, compared with those fed on negative control diet. Concerning the results of garlic powder supplementation, the obtained results of the current study agree with those of Rahimi et al., (2011) who reported that the addition of herbal extracts (thyme $0.1 \%$, coneflower $0.1 \%$ and garlic $0.1 \%$ ) to broiler diets at the 42 days of age significantly $(\mathrm{P} \leq 0.05)$ improved FCR. performance and consequently improved carcass measurements.

These results agree with those stated by Narimani-Rad et al. (2011) who reported that broilers fed on diet with mixed of OEO at level $1 \%$ and $0.5 \%$ ziziphora plus $0.5 \%$ peppermint had significant effect on some carcass characterization such as higher carcass yield $(70.76 \%$ of body weight), lowest abdominal fat deposition (2.34\%) and lowest gastrointestinal weight $(6.34 \%)$ compared to the control (69.14, 3.52 and $6.75 \%$, respectively).

\section{Mortality rate:}

Data reported in Table (9) show significant variations $(\mathrm{P} \leq 0.05)$ in mortality rate $(\%)$ due to the treatments applied. The lowest mortality rate was observed in groups of chicks fed diets supplemented with either OEO at level $1.5 \mathrm{~g} / \mathrm{kg} \operatorname{diet}(\mathrm{T} 6)$, or GP level $0.2 \mathrm{~g} / \mathrm{kg}$ diet (T8) then antibiotic level of 1.0 $\mathrm{g} / \mathrm{kg}$ diet (T3) with the same average $(0.6 \%)$. While, those fed diets supplemented with GP at levels 0.1 and $0.3 \mathrm{~g} / \mathrm{kg}$ diet (T7 and $\mathrm{T} 9$ ) showed average mortality rate $(1.7 \%)$ with no significant differences between these treatments in mortality rate. However, chicks of control group showed the highest mortality rate $(8.3 \%)$. This might be attributed to the antimicrobial activities of both GP and OEO against pathogenic microorganism in gastrointestinal tract that resulted in a good health and consequence low mortality.

These results agree with those reported by many investigators who stated that feeding on diets supplemented with GP with different levels had 
significant increase in total white blood cell (TWBC) which reflects good immune response and consequently decrease mortality rate of broiler chicken (Fadlalla et al., 2010). In the present study OEO had relatively reduced mortality rate. This result is in agreement with those of Betancourt et al., (2014) who reported that broiler chicken fed diets supplemented with OEO showed a reduction of $59 \%$ in mortality from ascites compared with the control.

\section{Economic Efficiency}

Data listed in Table (10) reveal that the highest relative economic efficiency (EEf) was observed in the group of birds fed the diet supplemented with GP at level of $0.2 \mathrm{~g} / \mathrm{kg}$ diet (T8) being $162.6 \%$, followed by those fed diets supplemented with OEO at levels 1.5 and $1.0 \mathrm{~g} / \mathrm{kg}$ diets (T6 and T5) mounted 158.7

Table 8. Effect (Mean \pm SE) of dietary antibiotic, oregano essential oil and garlic powder levels on carcass traits of Japanese quail chicks at the end of experimental period

\begin{tabular}{|c|c|c|c|c|}
\hline \multirow[b]{2}{*}{ Treatments } & \multicolumn{4}{|c|}{ Carcass traits } \\
\hline & $\begin{array}{l}\text { Live body } \\
\text { weight(g) }\end{array}$ & $\begin{array}{c}\text { Carcass weight } \\
\%\end{array}$ & $\begin{array}{c}\text { Total giblets } \\
\%\end{array}$ & $\begin{array}{c}\text { Total edible parts } \\
\%\end{array}$ \\
\hline T1 & $244.9 \pm 1.05^{\mathrm{f}}$ & $60.6 \pm 0.44^{\mathrm{f}}$ & $4.7 \pm 0.23^{b}$ & $65.2 \pm 0.58^{\mathrm{e}}$ \\
\hline $\mathbf{T 2}$ & $250.4 \pm 1.05^{\mathrm{de}}$ & $62.0 \pm 0.44^{\mathrm{de}}$ & $4.8 \pm 0.23^{b}$ & $66.8 \pm 0.58^{\mathrm{cde}}$ \\
\hline T3 & $258.6 \pm 1.05^{\mathrm{c}}$ & $63.0 \pm 0.44^{\mathrm{bcd}}$ & $5.0 \pm 0.23^{a b}$ & $68.0 \pm 0.58^{\mathrm{bc}}$ \\
\hline T4 & $250.9 \pm 1.05^{\mathrm{de}}$ & $62.9 \pm 0.44^{\mathrm{bcd}}$ & $4.9 \pm 0.23^{b}$ & $67.8 \pm 0.58^{\mathrm{cd}}$ \\
\hline T5 & $262.9 \pm 1.05^{\mathrm{b}}$ & $64.3 \pm 0.44^{\mathrm{b}}$ & $5.4 \pm 0.23^{\mathrm{ab}}$ & $69.7 \pm 0.58^{b}$ \\
\hline T6 & $274.9 \pm 1.05^{\mathrm{a}}$ & $66.2 \pm 0.44^{\mathrm{a}}$ & $5.7 \pm 0.23^{\mathrm{a}}$ & $71.9 \pm 0.58^{\mathrm{a}}$ \\
\hline T7 & $252.0 \pm 1.05^{\mathrm{d}}$ & $62.7 \pm 0.44^{\text {cde }}$ & $4.9 \pm 0.23^{b}$ & $67.6 \pm 0.58^{\mathrm{cd}}$ \\
\hline T8 & $259.2 \pm 1.05^{\mathrm{c}}$ & $63.6 \pm 0.44^{\mathrm{bc}}$ & $5.1 \pm 0.23^{a b}$ & $68.6 \pm 0.58^{b c}$ \\
\hline T9 & $248.2 \pm 1.05^{\mathrm{e}}$ & $61.3 \pm 0.44^{\mathrm{ef}}$ & $4.8 \pm 0.23^{b}$ & $66.1 \pm 0.58^{\mathrm{de}}$ \\
\hline
\end{tabular}

a, b....and f means having different letters at the same column are significantly ( $\mathrm{P} \leq 0.05$ ) different.

$\mathrm{T} 1=$ Control, $\mathrm{T} 2=$ Antibiotic (Oxytetracyclin 20\% ) $0.5 \mathrm{~g} / \mathrm{kg}$ diet, $\mathrm{T} 3=$ Antibiotic (Oxytetracyclin $20 \%$ ) $1.0 \mathrm{~g} / \mathrm{kg}$ diet, $\mathrm{T} 4=$ Oregano oil $0.5 \mathrm{~g} / \mathrm{kg}$ diet, T5= Oregano oil $1.0 \mathrm{~g} / \mathrm{kg}$ diet, T6= Oregano oil $1.5 \mathrm{~g} / \mathrm{kg}$ diet, T7= Garlic powder $0.1 \mathrm{~g} / \mathrm{kg}$ diet, $\mathrm{T} 8=$ Garlic powder $0.2 \mathrm{~g} / \mathrm{kg}$ diet, $\mathrm{T} 9=$ Garlic powder $0.3 \mathrm{~g} / \mathrm{kg}$ diet.

Table 9. Effect (Mean \pm SE) of dietary antibiotic, oregano essential oil and garlic powder levels on mortality \% of Japanese quail chicks at the end of experimental period

\begin{tabular}{|c|c|}
\hline Treatments & $\begin{array}{c}\text { Mortality } \\
(\%)\end{array}$ \\
\hline T1 & $8.3 \pm 0.37^{\mathrm{a}}$ \\
\hline $\mathbf{T} 2$ & $5.6 \pm 0.37^{b}$ \\
\hline T3 & $0.6 \pm 0.37^{d}$ \\
\hline T4 & $5.0 \pm 0.37^{b}$ \\
\hline T5 & $3.3 \pm 0.37^{\mathrm{c}}$ \\
\hline T6 & $0.6 \pm 0.37^{\mathrm{d}}$ \\
\hline T7 & $1.7 \pm 0.37^{\mathrm{d}}$ \\
\hline T8 & $0.6 \pm 0.37^{\mathrm{d}}$ \\
\hline T9 & $1.7 \pm 0.37^{\mathrm{d}}$ \\
\hline
\end{tabular}

\section{Microbial population in small intestine content of quails}

Quails that were fed diets supplementation of OEO at levels 1.5 and $1.0 \mathrm{~g} / \mathrm{kg}$ diet showed higher $(\mathrm{P} \leq 0.05)$ decrease in total microbial and pathogens counts in small intestine parts followed by those fed diet supplemented with GP at level $0.2 \mathrm{~g} / \mathrm{kg}$ diet and quail birds fed diet supplemented with oxytetracycline $(1.0 \mathrm{~g} / \mathrm{kg}$ diet $)$ compared to control group (Table 11).
It is clear from the data presented in Table (11) that total microbial and pathogens counts in small intestine parts decreased by increasing the concentration of both OEO and GP supplementation levels which is attributed to increase their antimicrobial effect. The supplementation of OEO was more effective on pathogenic population than both GP and antibiotic.

Results obtained are in agreement with those reported by (Wenk, 2000 and Apajalahti et al., 2004) 
who found that the antimicrobial activity of essential oil reduced the pathogens colonization in the gastrointestinal tract and stimulate the growth of beneficial microorganisms.

Table 10. Effect (Mean \pm SE) of dietary antibiotic, oregano essential oil and garlic powder levels on economic efficiency $(\%)$ of Japanese quail chicks at the end of experimental period

\begin{tabular}{|c|c|}
\hline Treatments & $\begin{array}{c}\text { Relative economic efficiency } \\
(\%)\end{array}$ \\
\hline T1 & $100.0 \pm 0.58^{i}$ \\
\hline $\mathbf{T 2}$ & $119.2 \pm 0.58^{\mathrm{h}}$ \\
\hline T3 & $147.2 \pm 0.58^{\mathrm{d}}$ \\
\hline T4 & $126.5 \pm 0.58^{\mathrm{f}}$ \\
\hline T5 & $153.2 \pm 0.58^{\mathrm{c}}$ \\
\hline T6 & $158.7 \pm 0.58^{\mathrm{b}}$ \\
\hline $\mathbf{T 7}$ & $143.3 \pm 0.58^{\mathrm{e}}$ \\
\hline T8 & $162.6 \pm 0.58^{\mathrm{a}}$ \\
\hline T9 & $124.0 \pm 0.58^{\mathrm{g}}$ \\
\hline
\end{tabular}

a, b....i, means having different letters at the same column are significantly $(\mathrm{P} \leq 0.05)$ different.

$\mathrm{T} 1=$ Control, $\mathrm{T} 2=$ Antibiotic (Oxytetracyclin $20 \%$ ) $0.5 \mathrm{~g} / \mathrm{kg}$ diet, $\mathrm{T} 3=$ Antibiotic (Oxytetracyclin 20\% ) $1.0 \mathrm{~g} / \mathrm{kg}$ diet, $\mathrm{T} 4=$ Oregano oil $0.5 \mathrm{~g} / \mathrm{kg}$ diet, $\mathrm{T} 5=$ Oregano oil $1.0 \mathrm{~g} / \mathrm{kg}$ diet, $\mathrm{T} 6=$ Oregano oil $1.5 \mathrm{~g} / \mathrm{kg}$ diet, $\mathrm{T} 7=$ Garlic powder $0.1 \mathrm{~g} / \mathrm{kg}$ diet,

$\mathrm{T} 8=$ Garlic powder $0.2 \mathrm{~g} / \mathrm{kg}$ diet, $\mathrm{T} 9=$ Garlic powder $0.3 \mathrm{~g} / \mathrm{kg}$ diet.

Table 11. Microbial counts $(\log \mathrm{cfu} / \mathrm{g})($ Mean \pm SE) in small intestine contents of Japanese quails at the end of the experimental period

\begin{tabular}{|c|c|c|c|c|c|c|c|}
\hline \multicolumn{2}{|c|}{ Treatments } & \multicolumn{6}{|c|}{ Microbial populations in samples from the intestinal contents of broilers (log cfu/g) } \\
\hline Irea & ints & $\begin{array}{l}\text { Microbial } \\
\text { total count }\end{array}$ & $\begin{array}{c}\text { Yeasts \& } \\
\text { molds }\end{array}$ & $\begin{array}{c}\text { Pseudo. } \\
\text { aeruginosa }\end{array}$ & Staph. aureus & $\begin{array}{l}\text { Coliform } \\
\text { group }\end{array}$ & $\begin{array}{c}\text { Salmonella } \\
\text { \&Shigella }\end{array}$ \\
\hline \multirow{4}{*}{ T1 } & D & $9.0 \pm 0.15^{\mathrm{abc}}$ & $7.1 \pm 0.08^{\mathrm{a}}$ & $7.5 \pm 0.15^{\mathrm{a}}$ & $8.9 \pm 0.14^{\mathrm{abc}}$ & $8.5 \pm 0.14^{\text {cdef }}$ & $7.6 \pm 0.14^{\mathrm{ab}}$ \\
\hline & $\mathbf{J}$ & $9.0 \pm 0.15^{\mathrm{abcd}}$ & $5.0 \pm 0.08^{\mathrm{c}}$ & $7.6 \pm 0.15^{\mathrm{a}}$ & $9.3 \pm 0.14^{\mathrm{a}}$ & $9.0 \pm 0.14^{\mathrm{ab}}$ & $7.7 \pm 0.14^{\mathrm{a}}$ \\
\hline & I & $9.3 \pm 0.15^{\mathrm{a}}$ & $6.7 \pm 0.08^{\mathrm{b}}$ & $6.6 \pm 0.15^{\text {cde }}$ & $9.3 \pm 0.14^{\mathrm{a}}$ & $9.2 \pm 0.14^{\mathrm{a}}$ & $7.7 \pm 0.14^{\mathrm{abc}}$ \\
\hline & D & $8.8 \pm 0.15^{\text {abcdef }}$ & ND & $7.0 \pm 0.15^{\mathrm{bc}}$ & $8.0 \pm 0.14^{\mathrm{e}}$ & $8.3 \pm 0.14^{\mathrm{efg}}$ & $6.9 \pm 0.14^{\mathrm{def}}$ \\
\hline \multirow[t]{3}{*}{$\mathbf{T} 2$} & $\mathbf{J}$ & $8.8 \pm 0.15^{\text {abcdef }}$ & ND & $6.5 \pm 0.15^{\text {cdef }}$ & $8.7 \pm 0.14^{\mathrm{bcd}}$ & $8.0 \pm 0.14^{\mathrm{ghi}}$ & $7.4 \pm 0.14^{\mathrm{abc}}$ \\
\hline & I & $9.0 \pm 0.15^{\mathrm{abcd}}$ & ND & $5.5 \pm 0.15^{\mathrm{ijk}}$ & $8.9 \pm 0.14^{\mathrm{bcd}}$ & $8.6 \pm 0.14^{\text {bcde }}$ & $6.8 \pm 0.14^{\text {defg }}$ \\
\hline & D & $8.6 \pm 0.15^{\text {cdefg }}$ & ND & $6.5 \pm 0.15^{\mathrm{def}}$ & $7.6 \pm 0.14^{\mathrm{efg}}$ & $7.7 \pm 0.14^{\mathrm{hi}}$ & $6.9 \pm 0.14^{\mathrm{def}}$ \\
\hline \multirow[t]{3}{*}{ T3 } & $\mathbf{J}$ & $8.2 \pm 0.15^{\mathrm{ghi}}$ & ND & $6.1 \pm 0.15^{\text {fghi }}$ & ND & ND & $6.9 \pm 0.14^{\mathrm{def}}$ \\
\hline & I & $8.7 \pm 0.15^{\text {bcdefg }}$ & ND & $5.6 \pm 0.15^{\mathrm{jkl}}$ & $7.5 \pm 0.14^{\mathrm{e}}$ & $7.8 \pm 0.14^{\mathrm{ghi}}$ & ND \\
\hline & D & $8.6 \pm 0.15^{\text {cdefg }}$ & ND & $6.9 \pm 0.15^{\mathrm{bcd}}$ & $7.6 \pm 0.14^{\mathrm{efg}}$ & $8.0 \pm 0.14^{\text {ghi }}$ & $7.2 \pm 0.14^{\mathrm{bcd}}$ \\
\hline \multirow[t]{3}{*}{ T4 } & $\mathbf{J}$ & $8.3 \pm 0.15^{\text {ghi }}$ & ND & $6.4 \pm 0.15^{\text {efg }}$ & $7.6 \pm 0.14^{\mathrm{efg}}$ & $7.6 \pm 0.14^{\mathrm{i}}$ & $7.5 \pm 0.14^{\mathrm{abc}}$ \\
\hline & I & $9.0 \pm 0.15^{\text {abcde }}$ & ND & $5.5 \pm 0.15^{\mathrm{kl}}$ & $8.4 \pm 0.14^{\mathrm{d}}$ & $8.5 \pm 0.14^{\operatorname{defg}}$ & ND \\
\hline & D & $8.2 \pm 0.15^{\mathrm{ghi}}$ & ND & $5.5 \pm 0.15^{\mathrm{kl}}$ & $7.3 \pm 0.14^{\mathrm{gh}}$ & $7.6 \pm 0.14^{\mathrm{i}}$ & $6.5 \pm 0.14^{\mathrm{fgh}}$ \\
\hline \multirow[t]{3}{*}{ T5 } & $\mathbf{J}$ & $7.6 \pm 0.15^{\mathrm{j}}$ & ND & $5.8 \pm 0.15^{\mathrm{ijk}}$ & $7.0 \pm 0.14^{\mathrm{h}}$ & ND & $6.4 \pm 0.14^{\mathrm{gh}}$ \\
\hline & I & $8.0 \pm 0.15^{\text {fghi }}$ & ND & $5.0 \pm 0.15^{\mathrm{m}}$ & $7.3 \pm 0.14^{\mathrm{gh}}$ & $7.7 \pm 0.14^{\mathrm{hi}}$ & $7.2 \pm 0.14^{\mathrm{bcd}}$ \\
\hline & D & $8.0 \pm 0.15^{\mathrm{hij}}$ & ND & $5.2 \pm 0.15^{\mathrm{lm}}$ & $7.0 \pm 0.14^{\mathrm{h}}$ & ND & $6.1 \pm 0.14^{\mathrm{h}}$ \\
\hline \multirow[t]{3}{*}{ T6 } & $\mathbf{J}$ & ND & ND & $5.5 \pm 0.15^{1 \mathrm{k}}$ & ND & ND & $5.3 \pm 0.14^{\mathrm{i}}$ \\
\hline & I & $7.9 \pm 0.15^{\mathrm{ij}}$ & ND & ND & ND & $7.0 \pm 0.14^{\mathrm{j}}$ & ND \\
\hline & D & $8.8 \pm 0.15^{\text {abcdef }}$ & $5.0 \pm 0.08^{\mathrm{c}}$ & $7.5 \pm 0.15^{\mathrm{a}}$ & $8.5 \pm 0.14^{\mathrm{cd}}$ & $8.4 \pm 0.14^{\text {defg }}$ & $7.2 \pm 0.14^{\text {bcd }}$ \\
\hline \multirow[t]{3}{*}{ T7 } & $\mathbf{J}$ & $8.5 \pm 0.15^{\operatorname{defg}}$ & $7.0 \pm 0.08^{f}$ & $7.3 \pm 0.15^{\mathrm{ab}}$ & $9.1 \pm 0.14^{\mathrm{ab}}$ & $8.1 \pm 0.14^{\mathrm{fgh}}$ & $7.6 \pm 0.14^{\mathrm{ab}}$ \\
\hline & $\mathbf{I}$ & $9.2 \pm 0.15^{\mathrm{ab}}$ & $5.0 \pm 0.08^{c}$ & $6.3 \pm 0.15^{\text {efgh }}$ & $9.1 \pm 0.14^{\mathrm{ab}}$ & $9.0 \pm 0.14^{\mathrm{ab}}$ & $6.6 \pm 0.14^{\mathrm{fg}}$ \\
\hline & D & $8.4 \pm 0.15^{\text {efgh }}$ & ND & $6.0 \pm 0.15^{\text {ghij }}$ & $7.4 \pm 0.14^{\text {fgh }}$ & $7.8 \pm 0.14^{\mathrm{hi}}$ & $6.7 \pm 0.14^{\mathrm{efg}}$ \\
\hline \multirow[t]{3}{*}{ T8 } & $\mathbf{J}$ & $7.7 \pm 0.15^{\mathrm{j}}$ & ND & $5.9 \pm 0.15^{\mathrm{hijk}}$ & ND & ND & $7.2 \pm 0.14^{\mathrm{bcd}}$ \\
\hline & I & $8.2 \pm 0.15^{\mathrm{ghi}}$ & ND & $5.0 \pm 0.15^{\mathrm{m}}$ & $7.8 \pm 0.14^{\mathrm{ef}}$ & $8.4 \pm 0.14^{\text {defg }}$ & $6.8 \pm 0.14^{\mathrm{efg}}$ \\
\hline & D & $8.8 \pm 0.15^{\text {bcdef }}$ & $4.7 \pm 0.08^{\mathrm{d}}$ & $7.0 \pm 0.15^{\mathrm{bc}}$ & $8.5 \pm 0.14^{\mathrm{d}}$ & $8.3 \pm 0.14^{\mathrm{efg}}$ & $7.2 \pm 0.14^{b c d}$ \\
\hline \multirow[t]{2}{*}{ T9 } & $\mathbf{J}$ & $8.6 \pm 0.15^{\text {cdefg }}$ & $5.0 \pm 0.08^{\mathrm{c}}$ & $6.7 \pm 0.15^{\text {cde }}$ & $8.8 \pm 0.14^{\mathrm{bcd}}$ & $8.8 \pm 0.14^{\mathrm{abcd}}$ & $7.6 \pm 0.14^{\mathrm{ab}}$ \\
\hline & I & $9.1 \pm 0.15^{\mathrm{abc}}$ & $5.0 \pm 0.08^{\mathrm{cd}}$ & $6.0 \pm 0.15^{\mathrm{hijk}}$ & $9.1 \pm 0.14^{\mathrm{ab}}$ & $8.9 \pm 0.14^{\mathrm{abc}}$ & $7.1 \pm 0.14^{\text {cde }}$ \\
\hline
\end{tabular}

a, b....m, means having different letters at the same column are significantly $(\mathrm{P} \leq 0.05)$ different. Whereas; $\mathrm{D}=\mathrm{Duodenum}, \mathrm{J}=$ Jejunum and I=Ilium (Intestinal parts), $\mathrm{ND}=$ Not Detected

$\mathrm{T} 1=$ Control, $\mathrm{T} 2=$ Antibiotic (Oxytetracyclin $20 \%$ ) $0.5 \mathrm{~g} / \mathrm{kg}$ diet, $\mathrm{T} 3=$ Antibiotic (Oxytetracyclin 20\% ) $1.0 \mathrm{~g} / \mathrm{kg}$ diet, $\mathrm{T} 4=$ Oregano oil $0.5 \mathrm{~g} / \mathrm{kg}$ diet, $\mathrm{T} 5=$ Oregano oil $1.0 \mathrm{~g} / \mathrm{kg}$ diet, $\mathrm{T} 6=$ Oregano oil $1.5 \mathrm{~g} / \mathrm{kg}$ diet, $\mathrm{T} 7=\mathrm{Garlic}$ powder $0.1 \mathrm{~g} / \mathrm{kg}$ diet, $\mathrm{T} 8=$ Garlic powder $0.2 \mathrm{~g} / \mathrm{kg}$ diet, $\mathrm{T} 9=$ Garlic powder $0.3 \mathrm{~g} / \mathrm{kg}$ diet. 


\section{CONCLUSION}

From the current study, it could be concluded that the improvement in productive performance of quail birds as a response to adding oregano essential oil (OEO) levels to quail diets seems to be adequate to achieve the favorable obtained results followed by adding garlic powder (GP) then antibiotic (oxytetracycline) levels compared to control. The highest significant improvement in the productive performance was observed in quail birds fed diet supplemented with OEO at level of $1.5 \mathrm{~g} / \mathrm{kg}$ diet followed by those fed diet supplemented with OEO at level $1.0 \mathrm{~g} / \mathrm{kg}$ diet then those fed diet supplemented with GP at level of $0.2 \mathrm{~g} / \mathrm{kg}$ diet. However, from the economic point of view, it could be concluded that feeding on the basal diet supplemented with GP at level of $0.2 \mathrm{~g} / \mathrm{kg}$ diet had lower feed cost than feeding on basal diet supplemented with OEO both level 1.5 and $1.0 \mathrm{~g} / \mathrm{kg}$ diet. Finally, the addition of both oregano essential oil (OEO) and garlic powder (GP) in quail diets could be used as an alternative growth promoter to antibiotics in poultry production.

\section{ACKNOWLEDGEMENT}

The authors would like to present deep gratefulness and appreciation to Agriculture Faculty, Benha University, Egypt (www.bu.edu.eg) for giving them the opportunity to fulfil this study.

\section{REFFERENCES}

Abdel-Wareth, A. A., S. Kehraus, F. Hippenstiel and K. Südekum, 2012. Effects of thyme and oregano on growth performance of broilers from 4 to 42 days of age and on microbial counts in crop, small intestine and caecum of 42-day-old broilers. Animal Feed Science and Technology, 178: 198202.

Alp, M., M. Midilli, N. Kocabağlı, H. Yılmaz, N. Turan, A. Gargilı and N. Acar, 2012. The effects of dietary oregano essential oil on live performance, carcass yield, serum immunoglobulin $\mathrm{G}$ level, and oocyst count in broilers. Journal Applied Poultry Research, 21:630-636.

American Public Health Association, 1993. Standard Methods for the Examination of Dairy Products, 16th ed. APHA, Washington, DC.

Aouadi R., A. Aouidet, A. Elkadhi, M. C. Ben Rayana, H. Jaafoura, B. Tritar and K. Nagati, 2000. Effect of garlic (Allium sativum) on lipid metabolism in male rats. Nutrition Research, 20: 273-280

Apajalahti J., A. Kettunen and H. Graham, 2004. Characteristics of the gastrointestinal microbial communities, with special reference to the chicken. World's Poultry Science Journal, 60:223-232.

Apitz-Castro R., S. Cabrera, M. R. Cruz, E. Ledezma and M. K. Jain, 1983. Effects of garlic extracts and of three pure components isolated from it on human platelet aggregation, arachidonate metabolism, release reaction and platelet ultrastructure. Thrombosis Research, 32: 155-169.

Azaz A. D., H. A. Irtem, M. Kurkcuoğlu and K. H. C. Baser, 2004. Composition and the in vitro antimicrobial activities of the essential oils of some Thymus species. Zeitschrift für Naturforschung C A Journal of Biosciences, 59: 75-80.

Bagamboula C., M. Uyttendaele and J. Debevere, 2004. Inhibitory effect of thyme and basil essential oils, carvacrol, thymol, estragol, linalool and p-cymene towards Shigella sonnei and $S$ flexneri. Food Microbiology, 21: 33-42.

Basmacioğlu H. Ö. Tokuşoğlu and M. Ergül, 2004. The effect of oregano and rosemary essential oils or $\alpha$-tocopheryl acetate on performance and lipid oxidation of meat enriched with n-3 PUFAs in broilers. African Journal of Animal Science, 34: 197-210.

Ben Arfa A., S. Combes, L. Preziosi-Belloy, N. Gontard and P. Chalier, 2006. Antimicrobial activity of carvacrol related to its chemical structure. Lett. Applied Microbiology, 43:149154.

Betancourt L., F. Rodriguez, V. Phandanouvong, C. Ariza-Nieto, M. Hume, D. Nisbet, G. AfanadorTellez, A. M. V. Kley and A. Nalian, 2014. Effect of Origanum chemotypes on broiler intestinal bacteria. Poultry Science, 93 :25262535

Bozkurt M., K. Küçükyılmaz, A. U. Çatlı and M. Çınar, 2009. Effect of dietary mannan oligosaccharide with or without oregano essential oil and hop extract supplementation on the performance and slaughter characteristics of male broilers. South Africa Journal of Animal Science, 39 (3): 223-232.

Broody S., 1949. Bioenergetics and growth . Reinhod publication crop.; New york, Ny.

Bunyapraphatsara N., 2007. Utilization of medicinal plants in animal production. The $11^{\text {th }}$ International Congress, Leiden, The Netherlands, Phytopharmcology. Chickens Annual Animal Science, 10: 157-165.

Cabuk M., A. Alcicek, M. Bozkurt and N. Imre, 2003. Antimicrobial properties of essential oils isolated from aromatic plants and using possibility as alternative feed additives. In: 11 . National Animal Nutrition Congress, pp: 184187.

Çabuk M., S. Eratak, A. Alçicek, and M. Bozkurt, 2014. Effects of Herbal Essential Oil Mixture as a Dietary Supplement on Egg Production in Quail. Science World Journal, 1-4.

Chang K. J. and S. H. Cheong, 2008. Volatile organosulfur and nutrient compounds from garlic by cultivating areas and processing methods. FASEB Journal, 22: 1108-2. 
Chowdhury S. R., S. D. Chowdhury and T. K. Smith, 2002. Effects of dietary garlic on cholesterol metabolism in laying hens. Poultry Science, 81: $1856-1862$.

Corzo-Martínez M., N. Corzo, and M. Villamiel, 2007. Biological properties of onions and garlic. Trends Food Science Technology, 18: 609-625.

Dickens J. A., M. E Berrang and N. A. Cox, 2000. Efficacy of herbal extract on microbiological quality of broiler carcass during simulated chill. Poultry Science, 79: 1200-1203.

Dorhoi A., V. Dobrean, M. Zăhan and P. Virag, 2006. Modulatory effects of several herbal extracts on avian peripheral blood cell immune responses. Phototherapy Research. 20: 352-358.

Duncan D. B., 1955. The multiple range and multiple F. Test. Biometries, 11:1-42.

Ertas O. N., T. Guler, M. Ciftci, B. Dalkilic, and O. Yilmaz, 2005. The effect of a dietary supplement coriander seeds on the fatty acid composition of breast muscle in Japanese quail. Revue de Médecine Vétérinaire, 156:514-518.

Fadlalla, I. M., T. Mohammed, B. H. and A. O. Bakhiet, 2010. Effect of feeding garlic on the performance and immunity of broilers. Asian Journal Poultry Science, 1-8.

Florou-Paneri P., I. Giannenas, E. Christaki, A. Govaris and N. Botsoglou, 2006. Performance of chickens and oxidative stability of the produced meat as affected by feed supplementation with oregano, vitamin $\mathrm{C}$, vitamin $\mathrm{E}$ and their combinations. Archiv für Geflugelkunde 70: 232240.

Fotea L., E. Costăchescu, G. Hoha and D. Leonte, 2008. The effect of oregano essential oil (Origanum vulgar L.) on broiler performance. Lucrări Ştiinţifice, 53: 253-256.

Fukayama E. H., A. G. Bertechini, A. Geraldo, R. K. Kato and L. D. S. Murgas, 2005. Oregano extract as an additive in the broiler diet. Revista Brasileira de Zootecnia, 34: 2316-2326.

Giannenas, I., P. Florou-Paneri, N. A. Botsoglou, E. Christaki and A. B. Spais, 2005. Effect of supplementing feed with oregano and/or $\alpha$ tocopheryl acetate on growth of broiler chickens and oxidative stability of meat. Journal of Animal Feed Science, 14: 521-535.

Giannenas I., P. Florou-Paneri, M. Papazahariadou, E. Christaki, N. A. Botsoglou and A. B. Spais, 2003. Effect of dietary supplementation with oregano essential oil on performance of broilers after experimental infection with Eimeria tenella. Archiv of Animal Nutrition 57: 99-106.

Hassan, I. I., A. A. Askar and G. A. El-Shourbagy, 2004. Influence of some medicinal plants on performance ; physiological and meat quality traits of broiler chicks. Egyptian Poultry Science, 24: 247-266.
Hernandez F., J. Madrid, V. Garcia, J. Orengo and M. D. Megias, 2004. Influence of two plant extracts on broilers performance, digestibility, and digestive organ size. Poultry Science, 83: 169174.

Iwalokun B. A., A. Ogunledun, D. O. Ogbolu, S. B. and J. Jimi-Omojola, 2004. In vitro antimicrobial properties of aqueous garlic extract against multidrug-resistant bacteria and Candida species from Nigeria. Journal of Medicinal Food,7: 327333.

Jamroz, D. and C. Kamel, 2002. Plant extracts enhance broiler performance. In non-ruminant nutrition: Antimicrobial agents and plant extracts on immunity, health and performance. Journal Animal Science, 80 (E. Suppl.1): pp.41.

Kim S. G., S. Y. Nam, H. C. Chung, S. Y. Hong and K. H. Jung, 1995. Enhanced Effectiveness of Dimethyl-4, 4 "-dimethoxy-5, 6, 5", 6 “dimethylene dioxybiphenyl-2, 2"-dicarboxylate in Combination with Garlic Oil against Experimental Hepatic Injury in Rats and Mice. The Journal of pharmacy and pharmacology, 47: 678-682.

Kim Y. J., S. K. Jin and H. S. Yang, 2009. Effect of dietary garlic bulb and husk on the physicochemical properties of chicken meat. Poultry Science, 88: 398-405.

Lee K. W., H. Everts, H. J. Kappert, M. Frehner, R. Losa and A. C. Beynen, 2003. Effects of dietary essential oil components on growth performance, digestive enzymes and lipid metabolism in female broiler chickens. British Poultry Science, 44: 450457.

Lee K. W., H. Everts and A. C. Beynen, 2004. Essential oils in broiler nutrition. International Journal of Poultry Science, 3: 738-752.

Lihua C., Y. Ying, L. Yifu and C. Lei, 2007. Effects of oregano oil on growth performance and carcass quality of broilers. China Poultry 29: 9-11.

McMahon F. G. and R. Vargas, 1993. Can garlic lower blood pressure? A pilot study. Pharmacother. The Journal of Human Pharmacology and Drug Therapy, 13: 406-407.

Modeva T. and Y. Profirov, 2003. Influence of the oregano etheric oil on the weight gain and some blood biochemical indices in chickens. Zhivotnovdni Nauki Bulg.

Moyers S. B., 1996. Garlic in health, history, and world cuisine (Suncoast Press).

Narimani-Rad, M., A. Nobakht, H. A. Shahryar, J. Kamani and A. Lotfi, 2011. Influence of dietary supplemented medicinal plants mixture (Ziziphora, Oregano and Peppermint) on performance and carcass characterization of broiler chickens. Journal of Medical Plant Research, 5(23): 5626-5629.

NRC., 1994. Nutrient Requirements of Poultry. $9^{\text {th }}$ rev. ed. Natl. Acad. Press, Washington, DC.Whey 
permeate containing $80 \%$ lactose was obtained from Berner Foods Inc (Roscoe, IL).

Onibi G. E., O. E. Adebisi, A. N. Fajemisin, A. V. Adetunji, 2009. Response of broiler chickens in terms of performance and meat quality to garlic (Allium sativum) supplementation. African Journal of Agriculture Researches, 4: 511-517.

Penalver P., B. Huerta, C. Borge, R. Astorga, R. Romero and A. Perea, 2005. Antimicrobial activity of five essential oils against origin strains of the Enterobacteriaceae family. Acta Pathologica, Microbiologica, et Immunologica Scandinavica, 113: 1-6.

Raeesi, M., S. A. Hoseini-Aliabad, A. Roofchaee, S. A. Zare and. S. Pirali, 2010. Effect of periodically use of garlic (Allium sativum) powder on performance and carcass characteristics in broiler chickens. World Academy of Science, Engineering and Technology, 44: 1213- 1219.

Rahimi, S., Z. Teymouri Zadeh, M. A. Karimi Torshizi, R. Omidbaigi and H. Rokni, 2011. Effect of the three herbal extracts on growth performance, immune system, blood factors and intestinal selected bacterial population in broiler chickens. Journal of Agriculture Science and Technology, 13:527-539.

Sallam K. I., M. Ishioroshi and K. Samejima, 2004. Antioxidant and antimicrobial effects of garlic in chicken sausage. LWT-Food Science Technology, 37: 849-855.

SAS, 2004. SAS/STAT guide for personal computers (SAS Institute).

Sumiyoshi H., 1997. New pharmacological activities of garlic and its constituents. Nihon yakurigaku zasshi. Folia pharmacologica Japonica. 110: 93 97.

Symeon G. K., C. Zintilas, A. Ayoutanti, J. A. Bizelis and S. G. Deligeorgis 2009. Effect of dietary oregano essential oil supplementation for an extensive fattening period on growth performance and breastmeat quality of female medium-growing broilers. Canadian Journal of Animal Science, 89:331-334.

Tiihonen, K., H. Kettunen, M. H. L. Bento, M. Saarinen, S. Lathinen, A. C. Ouwehand, H. Schulze and N. Rautonen, 2010. The effect of feeding essential oils on broiler performance and gut microbiota. British Poultry Science, 51: 381392.

Tollba, A. A. H. and M. S. H. Hassan, 2003. Using some natural additives to improve physiological and productive performance of broiler chicks under high temperature conditions. 2-Black Cumin (Nigella sativa) or Garlic (Allium). Egyptian Poultry Science, 23: 327-340.

Wenk C. 2000. Recent advances in animal feed additives such as metabolic modifiers, antimicrobial agents, probiotics, enzymes and highly available minerals. Asian-Australasian Journal of Animal Sciences, 13:86-95.

Williams, P. and R. Losa, 2001. The use of essential oils and their compounds in poultry nutrition. World Poultry, 17:14-15.

Williams P. and R. Losa, 2002. Blending essential oils for poultry. Feed Mix 10, 8-9.

Yin M. and Cheng W., 2003. Antioxidant and antimicrobial effects of four garlic-derived oregano sulfur compounds in ground beef. Meat Science, 63: 23-28.

\section{تأثير إضافة مسحوق الثوم، زيت البردقوش العطرى والمضاد الحيوى على اداء النمو وصفات الزبيحة والكائنات الحية الاقيقة المرضية في الأمعاء للسمانة زئن زنجبيل سعد محمد السبد، أسامة حسن منصور الجارحى، محمد محمد عبداللا، جمال على الاين الصياد osama.alsayed@fagr.bu.edu.eg قسم الإتتاج الحيوانسي، كلية الزراعة، جامعة بنها، مصر، *البريد الاككترونى}

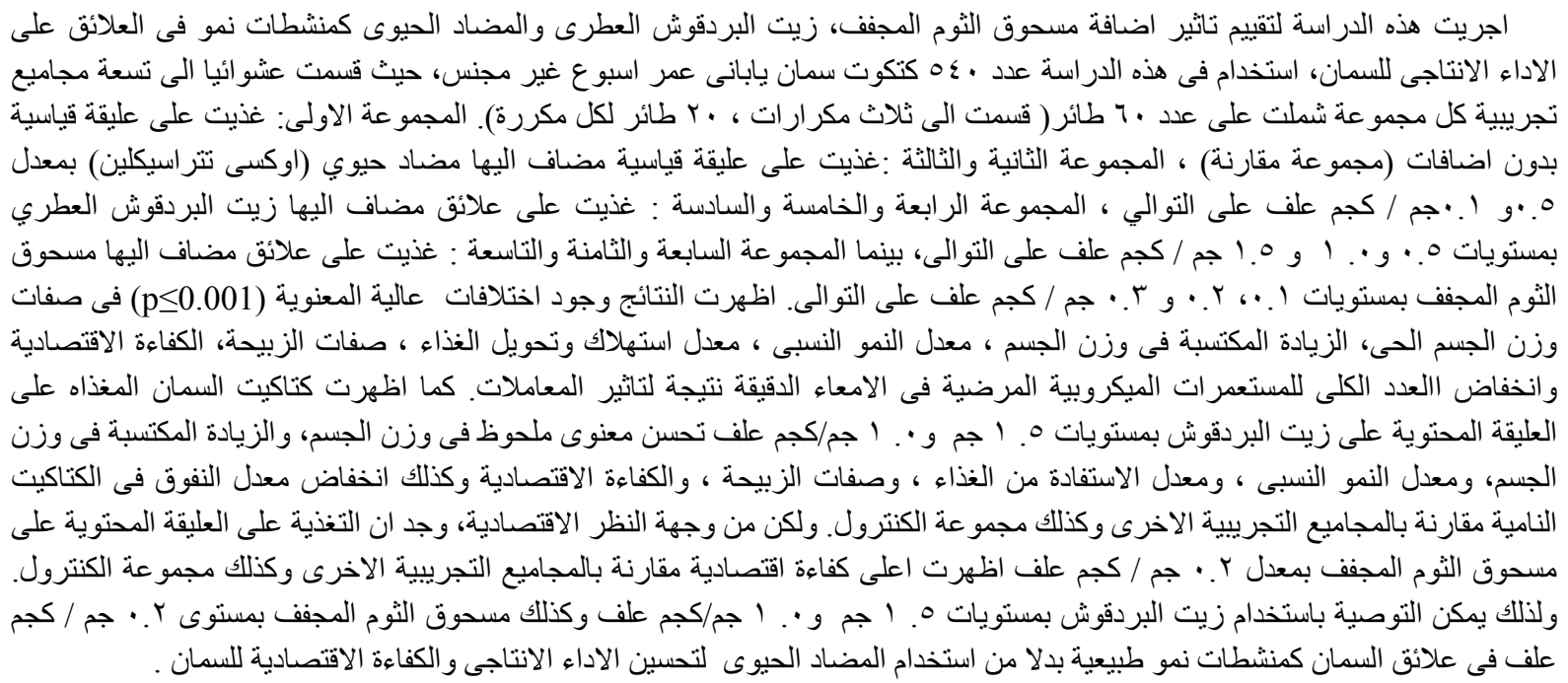

